\title{
Challenges and economic benefits of scrap metal trade at Kumasi Suame Magazine, Ghana.
}

\author{
Kwabena Offeh Gyimaha, Stephen Amoakohene, Wilberforce Kojo Mensah \\ ${ }^{\mathrm{a}}$ kogyimah@aamusted.edu.gh
}

Mechanical and Automotive Technology Education, Akenten Appiah-Menkah University of Skills Training and Entrepreneurial Development, Box 1277, Kumasi, Ghana

\begin{abstract}
The scrap metal trade has become the major source of livelihood for countless people at Suame Magazine. Most of the collectors are school drop-outs with very little knowledge about neither safe ways of practicing the trade nor the environmental implications of their activities such as the burning of cables to retrieve scrap metal. The trade has reduced unemployment to some extent and if it is given enough attention, the nation as a whole can benefit enormously from it. Demand for scrap metal will always be there due to the technological age we find ourselves in. Nonetheless, the trade has its challenges and negative impacts on the environment. Most respondents indicated that the scrap trade does not generate enough financial reward to cater for themselves and their families despite the risks and dangers they daily subject themselves to. However, it serves as a means to an end.
\end{abstract}

Keywords: scrap metals, recycling, suame magazine, scrap metal trade.

\section{Introduction}

The urban poor in Ghana have invented an endless series of survival strategies to endure the high rate of unemployment and widespread poverty by engaging in occupations such as waste scavenging. Scrap metal recycling has been in existence since the 18th century (Broni-Sefah, 2012). A waste scavenger is a person who salvages reusable or recyclable materials to sell. Scavenging from the waste stream is an important economic activity that provides income for over 15 million people worldwide, most of whom are in cities in developing countries, and it has a financial impact of several billions of US dollars every year (Medina, 2010). The industrial revolution which saw the emergence of large metallurgical industries was commonly regarded as the period when large scale metal recycling truly commenced (Broni-Sefah, 2012). If the scrap metal industry did not exist then there would be vast quantities of waste polluting our environment as well as an increased burden on primary resources (Emery et al., 2002). The scrap business as has been reported many times in literature as very lucrative and the demand for scrap by industries is quite enormous. Despite the burgeoning literature on this enterprise, little attention has been paid to the health risks associated with it (Owusu-Sekyere, 2014). The scavengers live and work under unhygienic conditions and the nature of their job exposes them to pathogenic bio-aerosols that may adversely affect their health. The impact of the scrap metal scavenging activities on the environment, health and social life of all stake holders in the trade would be examined in this paper.

This research examines the scrap metal trade at Suame Magazine a suburb of Kumasi. Suame Magazine is the largest informal sector village in the country accommodating several hundreds of small-scale engineering industries, repair works, scrap yards, workshops all with a working population of about 200,000 (Frimpong, 2011). The area is a major center for vehicle repair attracting vehicles from not only Ghana but from neighboring countries in the West African sub region. Scrap metal scavengers, comprising both children and adults, collect the scrap metal on a daily basis and sell it to the various scrap yard operators (middle men) which is later transported to the industries for recycling. Abudia Refinery in Suame Magazine is one of the small-scale metal manufacturing industries that patronize the scrap metal in Suame Magazine. There is a host of other small-scale metal manufacturing companies at Suame Magazine, most of which have not been registered. Aside the companies at Suame Magazine that make use of the Scrap metal, most of the scrap is transported to metal processing companies in Tema. 
Scrap metal recyclers in Ghana are mostly uneducated and poor. Most of them indulge in the trade without really knowing the health and environmental implications of their activities. A few of them being aware of the health implications still indulge in the trade due to poverty. Most of these people are from the rural areas in Ghana and have moved to the urban cities in search of employment. Since they are mostly uneducated and have scarcely any employable skills, they opt for scrap metal scavenging because it requires very little expertise and no academic qualifications. For some of them the trade is a lucrative one but for majority of them it is just a means of survival.

These recyclers collect the scrap metals without any protective clothing. They gather the metals from various places such as the dump sites, fitting shops, ports and harbors, industries, homes and many more. Broken down wheel barrows, copper cables, broken down cars, gas cookers, tins, fan parts, roofing sheets, metallic doors, metallic trunks, desktops and monitors are just a few of some of the items they collect as scrap metal. The gadgets containing metals are later pulled to pieces to retrieve the metallic parts. As recyclers hammer and chisel away parts of gadgets, they sometimes get cuts and bruises which may result in infections if not properly treated.

Their activities also pollute the environment as the burning of the plastic coatings on cables and other gadgets in order to expose metallic parts pollutes the air. The release of these toxic substances also contributes to global warming. The soil is also polluted by these activities as harmful chemical like lead and cadmium are leached into the soil and this affects soil water. People living in areas where these cables are burnt can contract lung and cardiovascular infections and even cancer. The chemicals released from the burning of the cables and gadgets can also be washed in to river bodies hence endangering aquatic life and contaminating river bodies (Akpoveta, 2010). Companies that buy the scrap metals for recycling also melt the metals before using and this also leads to the release of toxic substance into the environment.

Some of the scrap metal scavengers also collect steel cables which are not damaged and sell as scrap metals. There have been instances where telephone cables and electrical cables have been stolen by some unscrupulous people. This has created a stigma in the mind of citizens in Ghana about the scrap metal trade and sometimes the scavengers are called thieves or suspected to be thieves even when they are going about their business genuinely. There is also the perception that all who indulge in the scrap metal trade are school drop-outs which is not always the case. Some of the scavengers especially the young ones indulge in the trade not only for feeding and basic necessities but also for the payment of their school fees.

It has therefore become necessary that the scrap metal trade is studied to enable a better and safer handling of scrap metals in the country. In other to reduce the rate of pollution, protect the lives of the scrap scavengers, and help the government regulate the activities of the scrap trade.

\subsection{Purpose of study}

This project seeks to investigate the activities of scrap metal traders in the Kumasi Suame Metropolis. The specific objectives are (a) to determine challenges faced by scrap metal recyclers at Suame Magazine and (b) to determine the economic impact of the scrap metal trade at Suame Magazine.

\section{Methods}

Due to the nature of the units of analysis, the design of the study was based on both quantitative and qualitative strategies. Data was collected using interviews with structured questionnaires, informal discussions and observations (Forkor, 2017). The field observations were employed to authenticate the truthfulness of the data gathered after the various interviews. The data collected were analyzed with the use of the Statistical Package for Social Scientists (SPSS) version 16.

\subsection{Units of Analysis}

The units of analysis were scrap metal collectors (SMCs) and scrap dealers (SDs). The SMCs collect metal scraps within the Kumasi Metropolitan Area (KMA). They sell the collected scraps to the SDs located at specific points at Suame Magazine.

\subsection{Population and Sample}


The procedure for sampling was very important and considered paramount in the achievement of the objectives of this research. In this regard, the sample size was selected carefully in order to cover all the various aspects of the subject matter. Stratified random sampling was used to collect data in this study. 100 SMCs and 53 SDs were randomly selected from the study area and interviewed by the use of questionnaires.

\section{Results}

\subsection{Socio Demographic Background of Respondents}

The demographic data were collected to profile respondents for their suitability for the study. The data collected was in terms of their gender, age, educational level, category of scrap dealing

Table 3.1: Demography of respondents

\begin{tabular}{l|ll}
\hline Variables & Frequency $(f)$ & Percentage $(\%)$ \\
\hline Gender & & \\
Male & 130 & 85 \\
Female & 23 & 15 \\
Total & 153 & 100 \\
& & \\
Age (years) & & \\
$10-20$ & 54 & 35 \\
$20-30$ & 61 & 40 \\
$30-40$ & 8 & 5 \\
Above 40 & 30 & 20 \\
Total & 153 & 100 \\
& & \\
Educational Level & & \\
Primary Education & 76 & 50 \\
JHS & 54 & 35 \\
SHS & 23 & 15 \\
Diploma/Degree & 0 & 0 \\
Category of scrap dealers & 153 & 100 \\
Scrap Metal Collectors (SMC) & 100 & 65 \\
Scrap Dealers (SD) & 53 & 35 \\
& 153 & \\
\hline & & \\
\hline
\end{tabular}

From Table 3.1 above, $85 \%$ of respondents are males whiles $15 \%$ are females. This result indicates that the scrap metal trade is male-dominated. It is not a surprising result since the trade is physically demanding and labour intensive. The information about age from Table 1 also shows that 115 respondents representing $65 \%$ are aged between 10-30 years. This show that scrap metal collectors and dealers at Suame Magazine are relatively youthful in age probably due to the fact that the trade is tideous and involves heavy lifting.

According to the demographic data, no respondent had a diploma or degree certificate. $50 \%$ of respondents were, however, primary school leavers, $35 \%$ are JHS leavers and $15 \%$ SHS leavers. This clearly indicates that the trade is dominated by school dropouts. This trade, requiring no degree or any special skill, therefore serves anyone who is strong, agile and willing. 


\subsection{Economic profitability of scrap metal trade at Suame Magazine, Kumasi}

Table 3.2.1: Types of scrap metals, sources and sorting methods

\begin{tabular}{|c|c|c|}
\hline Variables & Frequency $(f)$ & Percentage (\%) \\
\hline \multicolumn{3}{|c|}{ Types of Metals collected } \\
\hline Aluminium & 15 & 10 \\
\hline Steel & 15 & 10 \\
\hline Others & 123 & 80 \\
\hline Total & 153 & 100 \\
\hline \multicolumn{3}{|l|}{ Collection Sources } \\
\hline Dumpsite & 69 & 45 \\
\hline Mechanical Shops & 23 & 15 \\
\hline Homes/ Streets & 61 & 40 \\
\hline Total & 153 & 100 \\
\hline \multicolumn{3}{|l|}{ Sorting of Metals } \\
\hline Visual Inspection & 46 & 30 \\
\hline Manetic Detectors & 23 & 15 \\
\hline \multirow[t]{2}{*}{ Both } & 84 & 55 \\
\hline & 153 & 100 \\
\hline
\end{tabular}

From Table 3.2.1 above, most scrap dealers are interested in collecting all kinds of metals. Some however, 30 dealers representing $20 \%$ of respondents, are interested in collecting a single type of metals, either Aluminium or Steel. $45 \%$ of scrap dealers and collectors get their metals from dumpsites, $40 \%$ from homes and streets, whiles $15 \%$ concentrate at the mechanical shops for their collection points. Due to the lack of separation of waste at homes, most metals end up at the dumpsites in bulk or composite forms. Scrap waste collectors/recyclers at the dumpsites breakdown bulk wastes either by mechanical means using hand tools or by open incineration. Sorting of metals is accomplished by visual means or by the use of magnets. According to the survey results from Table 3.2.1, 30\% of respondents sort by visual means whiles $15 \%$ of respondents use magnets. Furthermore, $55 \%$ of respondents utilize both methods.

Table 3.2.2: Economic profitability of scrap business

\begin{tabular}{|c|c|c|c|c|}
\hline \multirow[t]{2}{*}{ Variables } & \multicolumn{2}{|c|}{ Agree } & \multicolumn{2}{|c|}{ Disagree } \\
\hline & $f$ & $\%$ & $f$ & $\%$ \\
\hline I always get enough scrap metal for my activity & 107 & 70 & 46 & 30 \\
\hline There are high financial rewards in the scrap metal business & 57 & 37 & 96 & 63 \\
\hline $\begin{array}{l}\text { The money I make from scrap metal business is enough to cater for myself } \\
\text { and my dependents }\end{array}$ & 40 & 26 & 113 & 73 \\
\hline People sell household scraps at exorbitant prices & 101 & 66 & 52 & 33 \\
\hline
\end{tabular}




\begin{tabular}{l|ccc}
\hline There are sometimes shortage of scrap metals which reduces profitability & 86 & 56 & 67 \\
$\begin{array}{l}\text { I will encourage my friend or family member to join the scrap metal } \\
\text { business }\end{array}$ & 61 & 40 & 93
\end{tabular}

From Table 3.2.2 scrap metals are very available for collection at Suame Magazine and its environs. $70 \%$ of attendants get enough scraps for the activities always. Most recyclers making $63 \%$ of respondents indicated they did not derive enough financial reward from the business. It is therefore no surprise to notice that only $26 \%$ of respondents are able to manage from the trade to absolutely cater for themselves and their dependents. Prices of scrap metals especially the ones collected from households are high. Only 33\% of respondents think that they get good deals from buying scraps from homes. Sometimes there are shortages of scrap metals which negatively affect trade. $56 \%$ of respondents think that scrap shortage reduces profitability. $60 \%$ of respondents fail to recommend the business to their families and friends.

\subsection{Challenges faced by scrap metal dealers}

Table 3: Challenges in scrap trade industry at Suame Magazine

\begin{tabular}{|c|c|c|c|c|}
\hline \multirow[t]{2}{*}{ Variables } & \multicolumn{2}{|c|}{ Agree } & \multicolumn{2}{|c|}{ Disagree } \\
\hline & $f$ & $\%$ & $f$ & $\%$ \\
\hline Transportation of scrap metals to scrapyards is expensive & 92 & 60 & 61 & 40 \\
\hline Collection and separation of scrap is tedious and risky & 99 & 65 & 54 & 35 \\
\hline No knowledge of government regulations concerning scrap metal business & 122 & 80 & 31 & 20 \\
\hline Weighing of the scraps for sale are not always accurate & 109 & 71 & 44 & 29 \\
\hline $\begin{array}{l}\text { There is risk of injury (cuts, fractures) when dismantling equipment to } \\
\text { retrieve metal parts }\end{array}$ & 145 & 95 & 8 & 5 \\
\hline Hazard of exposure to poisonous gases and corrosive substances & 99 & 65 & 54 & 35 \\
\hline $\begin{array}{l}\text { There are no associations to fight for the interests of those engaged in the } \\
\text { scrap business }\end{array}$ & 107 & 70 & 46 & 30 \\
\hline $\begin{array}{l}\text { No specialized equipment to help in the sorting and separation of scraps to } \\
\text { their constituent metals }\end{array}$ & 145 & 95 & 8 & 5 \\
\hline Lack of access to funding from banks & 115 & 75 & 38 & 25 \\
\hline
\end{tabular}

The scrap business at Suame Magazine has even more challenges besides procurement cost. $60 \%$ of correspondents indicated that transportation costs from collection sites to scrapyards are high. Moreover, collection and separation of scraps is very tedious, energy consuming and risky. There may actually be government regulation regarding the operation of metal scrap but $80 \%$ of respondents do not know of any regulation or policy concerning solid waste collection and treatment. This clearly indicates that the collection, sorting and transportation of metal scrap at Suame Magazine are not regulated. Collectors therefore have no training or skill to ensure safety practice. It is therefore not surprising that $95 \%$ of respondents indicated that there is risk of injury when dismantling bulk composites to recover or separate scraps. $65 \%$ of respondents specified that scrap dealers are very much exposed to poisonous gases and corrosive substances in their trade.

\section{Conclusions and Recommendations}

The scrap metal trade has employed a lot of the urban poor. It has become the major source of livelihood for countless people at Suame Magazine especially those who migrated from the northern part of Ghana in search of 
greener pastures and also the uneducated and unskilled members of the Suame community. To some of the collectors, the trade is a lucrative one and to the others, the trade is just a means of survival. Most of the collectors are school drop-outs with very little knowledge about neither safe ways of practicing the trade nor the environmental implications of their activities such as the burning of cables to retrieve scrap metal. The working conditions for the scrap metal collectors and dealers do not employ safety measures. There are several health risks and hazards associated with the scrap trade with the most common one being cuts from sharp objects. Most respondents indicated that the scrap trade does not generate enough financial reward to cater for themselves and their families despite the risks and dangers they daily subject themselves to. However, it serves as a means to an end. On the whole, the scrap metal trade generates some income though not enough and reduces poverty by employing the urban poor.

All scrap metal collectors should register with various groups and associations. By so doing the government agencies such as the environmental protection agency can identify and educate them on better ways of conducting their activities in order not to cause harm to themselves and the environment. The country's waste collection system must be revamped. The government must put measures in place to ensure separation of waste at workplaces and homes into plastics, metals, biodegradable and electronics. This would improve effective waste management and recycling in Ghana, and thus prevent hazardous exposure and damp sites visits.

\section{REFERENCES}

Akpoveta, O. V., Osakwe, S. A., Okoh, B. E., \& Otuya, B. O. (2010). Physicochemical characteristics and levels of some heavy metals in soils around metal scrap dumps in some parts of Delta State, Nigeria. Journal of applied sciences and environmental management, 14(4).

Broni-Sefah, K. (2012). A study of the scrap metal trade in the Kumasi Metropolitan Area (Doctoral dissertation).Emery, A., Williams, K. P., Griffiths, A. J. (2002). A review of the UK metals recycling industry. Waste and Management Research, UK.

Frimpong E. A. (2011). Suame Magazine makes a breakthrough. Retrieved from enochdarfahfrimpong.blogspot.com

Forkor, N. P. (2017). Scrap metal management practices in the Kumasi Suame Magazine industrial area of the Ashanti region of Ghana, challenges and prospects (Doctoral dissertation, University of Education, Winneba)

Medina, M. (2010). Scrap and Trade: Scavenging Myths. National Oceanic and Atmospheric Administration.

Retrieve from:(https://en.wikipedia.org/wiki/Suame_Magazine,_Kumasi)

Owusu-Sekyere, E. (2014). Scavenging for wealth or death? Exploring the health risk associated with waste scavenging in Kumasi, Ghana. Ghana Journal of Geography, 6, 63-80. 